\title{
Post-Transcriptional Regulation of Gnrhr: A Checkpoint for Metabolic Control of Female Reproduction
}

\author{
Angela K. Odle*(D), Melanie C. MacNicol, Gwen V. Childs and Angus M. MacNicol \\ Department of Neurobiology and Developmental Sciences, University of Arkansas for Medical Sciences, \\ Little Rock, AR 72205, USA; MacnicolMelanie@uams.edu (M.C.M.); ChildsGwenV@uams.edu (G.V.C.); \\ Angus@uams.edu (A.M.M.) \\ * Correspondence: akodle@uams.edu
}

check for updates

Citation: Odle, A.K.; MacNicol, M.C.; Childs, G.V.; MacNicol, A.M. Post-Transcriptional Regulation of Gnrhr: A Checkpoint for Metabolic Control of Female Reproduction. Int. J. Mol. Sci. 2021, 22, 3312. https:// doi.org/10.3390/ijms22073312

Academic Editor: Micheline Misrahi

Received: 9 February 2021

Accepted: 20 March 2021

Published: 24 March 2021

Publisher's Note: MDPI stays neutral with regard to jurisdictional claims in published maps and institutional affiliations.

Copyright: (c) 2021 by the authors. Licensee MDPI, Basel, Switzerland. This article is an open access article distributed under the terms and conditions of the Creative Commons Attribution (CC BY) license (https:// creativecommons.org/licenses/by/ $4.0 /)$.

\begin{abstract}
The proper expression of gonadotropin-releasing hormone receptors (GnRHRs) by pituitary gonadotropes is critical for maintaining maximum reproductive capacity. $\mathrm{GnRH}$ receptor expression must be tightly regulated in order to maintain the normal pattern of expression through the estrous cycle in rodents, which is believed to be important for interpreting the finely tuned pulses of GnRH from the hypothalamus. Much work has shown that Gnrhr expression is heavily regulated at the level of transcription. However, researchers have also discovered that Gnrhr is regulated post-transcriptionally. This review will discuss how RNA-binding proteins and microRNAs may play critical roles in the regulation of GnRHR expression. We will also discuss how these posttranscriptional regulators may themselves be affected by metabolic cues, specifically with regards to the adipokine leptin. All together, we present evidence that Gnrhr is regulated post-transcriptionally, and that this concept must be further explored in order to fully understand the complex nature of this receptor.
\end{abstract}

Keywords: gonadotropin-releasing hormone receptor; post-transcriptional control; leptin

\section{Introduction}

The hypothalamic-pituitary-gonadal (HPG) axis is a finely tuned, dynamic system that is heavily influenced by environmental factors. The female HPG axis is especially remarkable in that it is programmed to cycle every 30 days in humans [1] and every 4-6 days in mice [2] and rats [3] in order to maintain follicular development and maturation in preparation for conception. Indeed, researchers have found that many factors in the HPG axis "cycle" in the female, involving layer after layer of sophisticated regulation [4]. The cells within the pituitary that respond to hypothalamic and gonadal factors to maintain these reproductive cycles are the gonadotropes. Although they make up a relatively small percentage of the anterior pituitary, the gonadotropes are a powerful population of cells that must function properly in order for reproductive capacity to be maintained [5]. Gonadotropes are an extremely dynamic population of cells that are poised to discern discreet patterns of gonadotropin-releasing hormone $(\mathrm{GnRH})$ secretion from the hypothalamus [6-12]. These GnRH pulses are critical for directing the production and/or secretion of basal and stimulated levels of gonadotropins that subsequently control reproductive processes. Arguably, one of the most important products of the gonadotrope is the gonadotropin-releasing hormone receptor (GnRHR), the expression of which is necessary for the receipt and interpretation of GnRH pulses [6].

The GnRHR is a member of the G protein-coupled receptors and is one of the smallest receptors of this class in mammals [13]. GnRHR levels are considered to be the rate-limiting component of gonadotrope functions. Indeed, proper levels of the receptor are necessary for maintaining the production of the major gonadotrope products follicle-stimulating hormone (FSH) and luteinizing hormone (LH), and the concentration of GnRH receptors on the gonadotrope surface may actually dictate the preferential stimulation of gonadotropin 
transcription [6]. A seminal study by Savoy-Moore et al. detailed the pattern of GnRHR expression in the female rat pituitary through the estrous cycle using radiolabeled $\mathrm{GnRH}$ agonists [14]. The rat pituitary displays a significant increase in GnRH receptors from metestrus to diestrus, maintaining this high expression into the morning of proestrus, after which receptor expression rapidly declines. This study and others revealed that, in addition to changes occurring in GnRH pulses coming from the hypothalamus, GnRH receptor expression itself changes during the estrous cycle to prepare for the proestrous luteinizing hormone surge $[15,16]$. Thus began a decades-long investigation into the mechanisms behind regulation of GnRHR levels.

Although many of the studies investigating the regulation of GnRH receptor expression have focused on the gonadotrope, GnRH receptors are also found in the gonads [17-19], placenta [20], spinal cord [21], and brain (hippocampus, amygdala, septum, hypothalamus, and cortex) [22-26], as well as in other tissues in various species. For this review, we will focus on the regulation of GnRH receptor expression in the pituitary. Most of the research to date has focused on the transcriptional regulation of the Gnrhr gene. However, in this review we will discuss emerging evidence that GnRHR levels are regulated post-transcriptionally, and that organismal metabolic status may heavily influence this regulation. Most of this evidence comes from studies of gonadotrope cell lines and/or female mice, so this review will focus largely on female reproduction.

\section{Transcriptional Regulation of Gnrhr}

The transcriptional regulation of the Gnrhr gene is undoubtedly critical for the fully functional gonadotrope, and the nature of this regulation has been reviewed extensively [12,27-29]. In brief, it is well established that transcription of Gnrhr is stimulated by $\mathrm{GnRH}$, and that regulatory elements for $\mathrm{GnRH}$-mediated stimulation are contained within the $5^{\prime}$ region of the murine Gnrhr [12,30-32]. Activin, a product of the ovaries and of the pituitary itself that is known to potently stimulate Fshb gene transcription, was once believed to amplify GnRH-stimulated Gnrhr transcription [33,34]. However, recent evidence has called this into question $[35,36]$. Other studies have shown that estradiol $[30,37]$ and glucocorticoids [38] can stimulate Gnrhr transcription. Pituitary adenylate cyclase-activating polypeptide (PACAP) and steroidogenic factor-1 (SF-1) have been identified as important mediators of Gnrhr transcription [39-41], as has liver receptor homolog-1 (LRH-1) [42]. This list is not exhaustive, and Gnrhr is clearly highly regulated at the level of transcription, perhaps most significantly by GnRH itself. Newer evidence, however, has emerged indicating that regulation of this critical receptor extends well beyond transcription (Figure 1).

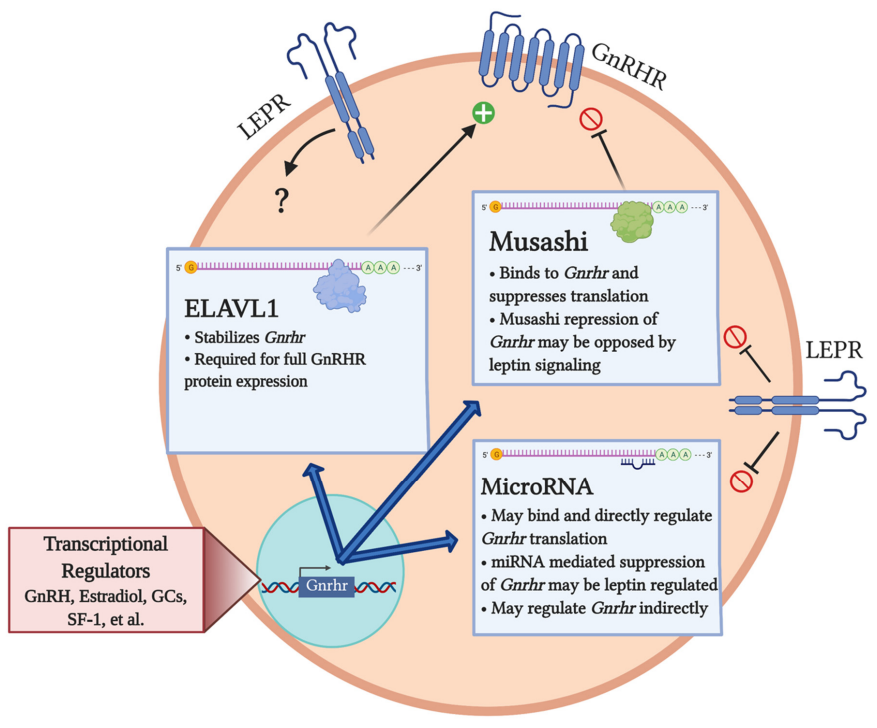

Figure 1. Post-transcriptional control of Gnrhr and the role of leptin. The proposed mechanisms for post-transcriptional control of Gnrhr are depicted, with leptin negatively regulating Musashi and 
microRNAs. The role of leptin in the regulation of ELAVL1 (if any) is unknown. Abbreviations: embryonic lethal abnormal vision like 1 (ELAVL1), leptin receptor (LEPR), glucocorticoids (GCs), steroidogenic factor-1 (SF-1).

\section{Post-Transcriptional Regulation of Gnrhr}

Discreet GnRH pulses increase the numbers of GnRH receptors in gonadotropes [43,44]. Although a great deal of GnRH-mediated stimulation of GnRHR exists at the level of transcription, GnRHR levels are also translationally regulated by GnRH. Studies from the mid-1990s showed that GnRH stimulates GnRHR protein levels without altering Gnrhr mRNA levels in the alpha T-3 cell line and in Xenopus oocytes [45]. The authors of this study suggested that the synthesis of GnRHR can be regulated at both transcriptional and post-transcriptional levels, depending on variables such as time and species. A second study by the same group demonstrated that the decrease in GnRHR following chronic stimulation with GnRH in alpha T3 cells is due to a decrease in Gnrhr mRNA translation [46]. Researchers therefore began exploring a new level of Gnrhr regulation, focusing on posttranscriptional mechanisms. We review here three mechanisms by which Gnrhr is regulated post-transcriptionally (Figure 1).

\section{1. miRNA Regulation of Gnrhr}

MicroRNAs (miRNA) are single-stranded RNAs ( 22 nucleotides) that bind and regulate target RNAs, leading to changes in translation or stability. The expression and function of gonadotrope miRNAs has been studied in LBT2 cells [47-50], rats [51,52], pigs [53,54], and mice [55-57]. Dicer is an endoribonuclease critical for the production of miRNAs from double-stranded mRNAs [58]. A gonadotrope-specific deletion of Dicer in mice has significant negative reproductive consequences [57]. Pituitaries from male gonadotropeDicer-null mice express much lower levels of the gonadotropin subunit mRNAs Fshb and $L h b$, as well as the shared alpha ( $C g a)$ subunit mRNA compared to controls, and females also show a significant decrease in Lhb and Cga (but not Fshb). Importantly, both males and females from this gonadotrope Dicer-null line show significant decreases in pituitary Gnrhr mRNA. Thus, the authors proposed that this decrease in Gnrhr mRNA is the result of imbalances in gonadotrope transcriptional suppressors and activators following the loss of DICER-dependent miRNAs (see Figure 1 in [57]). Based on in silico predictions, Gnrhr mRNA may also be targeted by a number of miRNAs (Table 1, [59]). Potential regulatory miRNAs include miR-669d-5p and miR-3061-3p, which are predicted to target both human and mouse Gnrhr 3' untranslated regions (UTRs) [4].

Table 1: Targetscan 7.2-predicted miRNA target sites within the 190 nucleotide mouse Gnrhr 3' UTR (ENST00000420975 (nucleotides 110-299)) [59,60]. The position of each miRNA target site is expressed as nucleotides from the $5^{\prime}$ end of the mGnrhr $3^{\prime}$ UTR. Target site conservation within either the human or rat Gnrhr $3^{\prime}$ UTR is indicated. For reference, our cloned 190 nucleotide mouse Gnrhr $3^{\prime}$ UTR contains three consensus Musashi binding elements (MBEs) (at positions 25-29, 106-111 and 143-148) as well as two atypical polyadenylation hexanucleotide sequences (AACAAA) at 174-179 and 181-186 [60].

While researchers are still determining which microRNAs are expressed in gonadotropes and how miRs may regulate gonadotrope functions, there have been several studies exploring the responses of gonadotrope miRNA to GnRH. An initial survey of miRNAs in LBT2 cells using multiple detection methods revealed a large number of miRNAs expressed in this gonadotrope cell line, with the exact number depending on the sensitivity of the method [47]. A test of GnRH responsiveness revealed selective upregulation of miR132/miR-212 (products of the same gene). A second study of miRNAs in the LßT2 cell line demonstrated that GnRH stimulates both an up- and down-regulation of gonadotrope miRNAs, confirming a strong upregulation of miR-132/miR-212 [48]. A focused investigation of miR-132 and miR-125b revealed a regulatory loop important for the desensitization of the gonadotrope to the GnRH signal, though no direct interaction with the Gnrhr transcript was 
discussed [50]. Rather, the authors found several downstream targets for both miRNAs that appear to be critical for proper gonadotrope responses to GnRH. The same group has also identified a role for miR-132/212 in GnRH-mediated stimulation of Fshb expression [49]. GnRH stimulation of primary porcine pituitary cell cultures also revealed both up- and down-regulated miRNAs, including miR-361-3p (downregulated) which the authors state is predicted to bind Gnrhr 3' UTR [53]. We note that Targetscan did not predict binding of miR-361-3p to the murine Gnrhr 3' UTR (Table 1). While the role and species-specific identity of miRNAs that may directly regulate Gnrhr mRNA translation remain to be fully determined, it is clear that miRNAs make a significant contribution to the transcriptional and/or post-transcriptional homeostasis of the gonadotrope in vivo [57]. Future studies of gonadotrope-specific miRNA modulations following physiological stimulations and targeted analyses of their ability to modulate Gnrhr mRNA translation and stability will be critical to clarify their regulatory impact.

Table 1. miRNAs predicted to bind the murine Gnrhr $3^{\prime}$ UTR.

\begin{tabular}{|c|c|c|c|c|}
\hline $\begin{array}{l}\text { Predicted } 3^{\prime} \text { UTR } \\
\text { Target Site }\end{array}$ & $\begin{array}{l}\text { Position in Mouse } \\
\text { Gnrhr } 3^{\prime} \text { UTR (ntds) }\end{array}$ & $\begin{array}{c}\text { Conserved in Human } \\
\text { Gnrhr } 3^{\prime} \text { UTR? }\end{array}$ & $\begin{array}{c}\text { Conserved in Rat } \\
\text { Gnrhr } 3^{\prime} \text { UTR? }\end{array}$ & $\begin{array}{l}\text { miRNA Target Site } \\
\text { Overlap with MBE? }\end{array}$ \\
\hline miR-150-5p & $1-8$ & & & \\
\hline $\operatorname{miR}-532-3 p$ & $2-8$ & & Yes & \\
\hline $\operatorname{miR}-669 d-5 p$ & $11-18$ & Yes & & \\
\hline miR-3089-5p & $17-23$ & & & \\
\hline miR-1199-5p & $19-25$ & & & Yes \\
\hline miR-3061-3p & $33-39$ & Yes & & \\
\hline miR-7223-5p & $66-72$ & & & \\
\hline miR-599 & $75-81$ & & & \\
\hline miR-467eh-5p/miR-668-5p & $79-85$ & & & \\
\hline $\mathrm{miR}-344-3 \mathrm{p} / \mathrm{miR}-410-3 \mathrm{p}$ & $83-89$ & & & \\
\hline miR-1981-3p & 106-112 & & & Yes \\
\hline miR-495-3p & $136-142$ & & Yes & \\
\hline miR-3065-5p & $137-143$ & & Yes & Yes \\
\hline miR-493-3p & $158-165$ & & Yes & \\
\hline miR-129-5p & 176-182 & & & \\
\hline $\operatorname{miR}-129-5 p$ & $183-189$ & & & \\
\hline
\end{tabular}

\subsection{Post-Transcriptional Regulation of Gnrhr mRNA by Musashi}

An in silico analysis of the Gnrhr mRNA regulatory $3^{\prime}$ untranslated region (3'UTR) by our laboratory revealed three consensus binding sites for the RNA-binding protein Musashi [60]. The Musashi gene family (Msi1 and Msi2) encodes sequence-specific regulators of target mRNA translation that have been implicated as critical determinants of stem cell fate [61]. In addition to pituitary stem cell expression, our recent work has found expression of both Msi1 and Msi2 throughout all hormone-producing cell lineages of the anterior pituitary [62] where they may function to modulate hormone secretion in response to organismal demands.

Using an electrophoretic mobility shift assay (EMSA), we showed that the Musashi1 protein (MSI1) interacts specifically with the murine Gnrhr $3^{\prime}$ UTR [60]. To test if MSI1 association enforced translational regulation through the Gnrhr $3^{\prime}$ UTR, we performed a series of dual luciferase mRNA reporter assays. We reported that MSI1 significantly repressed the translation of the Gnrhr $3^{\prime}$ UTR reporter mRNA [60]. Importantly, immunoprecipitation of MSI1 from female mouse pituitaries significantly enriched for the endogenous Gnrhr 
mRNA, confirming this relationship in the mouse pituitary. Not only did these studies identify a new mechanism for the regulation of GnRHR levels in the mouse, they also proposed a novel role for MSI in the regulation of mature, hormone-secreting pituitary cells. It will be important to define other MSI targets in these cells. As the levels of GnRHR change throughout the estrous cycle [14], it will also be important to determine if MSI plays a role in the stage-dependent expression of these receptors.

\subsection{Post-Transcriptional Regulation of Gnrhr by ELAVL1}

A second RNA-binding protein, embryonic lethal abnormal vision like 1 (ELAVL1/HuR), has been implicated as a post-transcriptional regulator of Gnrhr mRNA [63]. ELAVL1 is a member of the ELAV/Hu family of RNA-binding proteins that are known for their ability to bind AU-rich elements (AREs) to stabilize mRNA transcripts and thus promote translation [64]. In LBT2 cells, a gonadotrope model cell line, immunoprecipitation of ELAVL1 revealed a number of direct mRNA targets that are critical for gonadotropin synthesis and release, including the Gnrhr mRNA. Knockdown of the Elavl1 gene in these cells decreases Gnrhr mRNA significantly. Importantly, ELAVL1 binding was not altered by GnRH stimulation, although ELAVL1 interaction with certain other mRNAs was altered. The authors showed that ELAVL1 functions to stabilize Gnrhr mRNA, and that this stabilization is critical for full GnRHR protein expression. Since several other important gonadotrope genes were also associated with ELAVL1, this study suggests a broader role for ELAVL1 in regulating gonadotrope mRNA stability and translation.

\section{Metabolic Influences on the Post-Transcriptional Regulation of GnRHR Levels: A Role for Leptin}

The negative repercussions of nutritional unbalance, including obesity, high-fat diet, and caloric insufficiency upon reproduction are numerous. At the level of the pituitary, we know that diet-induced obesity (DIO) in mice can cause increased GnRH receptor levels and inappropriately high GnRH-stimulated LH secretion, similar to what is seen in polycystic ovarian syndrome (PCOS) $[65,66]$. While it is possible that several circulating metabolic factors are involved, most of what we currently know about the effects of metabolism on the post-transcriptional regulation of Gnrhr comes from studies of leptin. Leptin is an adipokine produced by white fat cells that signals the body's nutritional status to nearly every tissue in the body, including each tier of the HPG axis [67]. Leptin circulates in proportion to fat, such that lean individuals have normal or low-circulating leptin, whereas obese individuals have high-circulating leptin [68,69]. Maintaining levels of circulating leptin within a narrow optimal range is critical, as having low- or high-circulating leptin can lead to reproductive disorders [70-72]. For example, women with PCOS have been shown to have decreased leptin-LH pulse synchronization compared to control subjects [73]. Female (and most male) mice lacking the leptin gene (Lep/Lep) or leptin receptors (Lepr/Lepr) are infertile [74-76], and administration of leptin to Lep/Lep mice can restore fertility without a significant decrease in weight $[77,78]$. Importantly, all three tiers of the hypothalamic-pituitary-gonadal (HPG) axis express leptin receptors (LEPR) [67,79-81]. While much attention has been given to the important role leptin plays in the brain, work from our lab has revealed novel mechanisms by which leptin regulates reproduction at the level of the pituitary.

As mentioned above, gonadotropes must produce sufficient and appropriate amounts of GnRHR to maintain reproductive functions. Just as GnRH receptor levels change with the estrous cycle in rodents, so do the levels of gonadotrope LEPR. Our lab showed that, in both rats and mice, the overall percentage of pituitary cells expressing leptin receptors is significantly higher in proestrus and estrus compared to metestrus and diestrus [82]. When focusing on the gonadotropes, cells co-expressing LH and LEPR or FSH and LEPR increase from metestrus to diestrus, remaining high in proestrus decreasing by estrus. Also increasing from metestrus to diestrus are GnRHR proteins, suggesting that the increase in gonadotrope leptin sensitivity may indeed be needed to stimulate the cyclic rise in GnRHR.

In order to study the role of leptin in the regulation of GnRHR, we produced a gonadotrope-specific Lepr knockout line [82]. We found that leptin receptors on go- 
nadotropes are important for maximal reproductive competence, perhaps due to the reduced gonadotropin secretion seen in these female mice. A study of the pituitaries from these sub-fertile female gonadotrope Lepr-null mice revealed decreased GnRH receptor proteins with no change in Gnrhr mRNA [82]. We therefore hypothesized that leptin regulates gonadotrope functions, at least in part, by regulating Gnrhr at the post-transcriptional level.

We have demonstrated that MSI1 binds to Gnrhr in the mouse pituitary [60]. Leptin appears to exert a regulatory influence on this relationship as leptin stimulation of normal pituitary cells decreases Msil expression in vitro. In separate studies, we also showed that leptin can oppose MSI-mediated mRNA translational repression of the Pou1f1 (pituitaryspecific positive transcription factor 1) mRNA $3^{\prime}$ UTR in reporter assays [62]. Stimulation of primary pituitary cultures with recombinant mouse leptin resulted in an increase in GnRH binding sites and a decrease in MSI1 [60], supporting the hypothesis that leptin acts to oppose Musashi-directed repression of the Gnrhr mRNA in gonadotropes. Our ongoing studies will determine if, like Poulf1 mRNA translation [62], leptin acts to oppose MSI-mediated repression to promote Gnrhr mRNA translation in gonadotropes.

Metabolic disorders are associated with disordered levels of miRNA production and secretion (reviewed in [83]). Specifically, leptin has been shown to modulate miRNA levels (see [84-87] for a few recent examples), and we have demonstrated this in somatotropes [88]. Since our in silico analyses predicted binding sites for miRNAs within the $3^{\prime} \mathrm{UTR}$ of Gnrhr (Table 1), we wished to determine whether or not leptin may regulate Gnrhr posttranscriptionally via regulation of gonadotrope miRNA levels. To this end, we selected miRNAs from our in silico analysis and measured them in our control and gonadotropeleptin receptor-null female mouse pituitaries. One of these miRNAs, miR-669d, was found to be significantly increased in our gonadotrope-Lepr-null female pituitaries [4], consistent with the hypothesis that leptin downregulates gonadotrope miRNAs that can target the Gnrhr mRNA for repression. Future studies characterizing the gonadotrope microtranscriptome before and after leptin stimulation will determine if any of the miRNAs predicted to bind Gnrhr are metabolically sensitive. We also recognize that circulating miRNAs, which are altered with metabolic status, may play a role in Gnrhr regulation. Indeed, researchers have previously identified two miRNAs critical for LH secretion [89] that are dysregulated in the serum of anovulatory women [90].

\section{Future Directions: Developmental Regulation of GnRHR}

The Gnrhr transcript is one of the earliest detectable gonadotrope markers, first appearing around embryonic day 12.75-13.5 in mice [91,92]. The embryonic mouse gonadotropes have been shown to respond to GnRH by increasing secretion of LH on embryonic day 16 [92,93]. A study of male mice in which yellow fluorescent protein (YFP) is expressed in Gnrhr-expressing cells demonstrated that all LHB+ cells express GnRHR by embryonic day 16.5, whereas FSHß+ cells begin to express GnRHR around embryonic day 18.5, with full expression (all FSHß+ cells expressing GnRHR) not seen until postnatal day 7 (44). GnRH signals from the hypothalamus continue to activate gonadotropes into the postnatal days (rodents) and months (humans) (reviewed in [94]). Finally, at the initiation of puberty, GnRH pulse amplitude and frequency begin increasing, and male and female patterns of GnRH secretion are ultimately established [94]. Therefore, the proper expression of GnRH receptors during the embryonic and postnatal periods is critical for the development and refinement of the HPG axis. GnRH receptor transcript levels rise sharply in the postnatal weeks in rats, peaking before (male) or right around (female) the onset of puberty and declining into adulthood [95].

Also occurring during this postnatal period in rodents (often considered equivalent to the third-trimester in humans) is the remarkable postnatal leptin surge [96,97]. In rodents, this surge in leptin secretion occurs between PND 7 and 10, returns to adult levels by weaning, and is not associated with increased food intake or fat accumulation. Full and properly timed execution of the postnatal leptin surge has been found to be critical for the normal development of the pancreas, the kidney, the thymus, the ovaries, and 
hypothalamic neuronal and glial populations involved in metabolism, in addition to other areas in the brain [98-102]. One study in male and female rats used a leptin antagonist to block the surge and looked at changes in puberty markers [103]. The investigators found increased estradiol and Fshb production, along with increased kisspeptin receptor in the treated prepubertal females, indicating that the onset of puberty is perhaps advanced in this group. These findings demonstrate the sensitivity of the reproductive axis to the postnatal leptin surge. Investigators must work to determine how the regulation of $\mathrm{GnRH}$ receptor expression is influenced by leptin during this critical postnatal period.

Regulation of GnRH receptor expression is multifaceted, involving both transcriptional and post-transcriptional mechanisms, and clearly more research is required to elucidate the molecular pathways influencing gonadotropin release and their interactions with the metabolic axis, not just in the adult, but also during embryonic development. Indeed, leptin is permissive for puberty, and exogenous leptin can advance the onset of puberty in normal female mice [104-107]. To what extent do embryonic post-transcriptional pathways establish reproductive competence for the adult? In the adult, future studies will be necessary to assess the ability of gonadotrope miRNAs to directly modulate Gnrhr mRNA translation and assess their regulation by leptin-dependent signaling. It will prove illuminating to determine if MSI and ELAVL1 share mRNA targets within the gonadotrope population and, if so, whether they act antagonistically, cooperatively or independently to govern gonadotropin release. It will also prove helpful to know if MSI is regulated by GnRH and, conversely, if ELAVL1 is a target of leptin signaling. In addition to the Gnrhr mRNA, it is important to determine if there are other gonadotrope mRNAs subject to post-transcriptional regulation if these modulate estrus cycle function and/or reproductive competence.

Previous studies have reported that in addition to ELAVL1/HuR, other AU-rich binding proteins (e.g., tristetrapolin (TTP)/zinc finger protein 36 (ZFP36)) can sometimes collaboratively or antagonistically bind to the same target mRNA to enhance or attenuate translational regulation [108]. It remains to be determined if TTP or other AU-rich binding proteins contribute to Gnrhr mRNA translational regulation. An additional complexity that will need to be considered is the possibility of collaborative or antagonistic RNAbinding protein/miRNA competition for overlapping $3^{\prime}$ UTR target sites, particularly with relation to ELAVL1/HuR [109]. Of note, several putative miRNAs that target the Gnrhr mRNA translation overlap the MBEs (Table 1), and so it may prove informative to determine if miRNAs influence Musashi-dependent regulation. The competition between RNA-binding proteins and/or RNA-binding proteins and miRNA for a common binding site represents an interesting future area of study. Given the interest in HuR inhibitors as cancer therapeutics [110-112], researchers should determine whether or not these drugs have negative effects on the HPG axis (such as the destabilization of Gnrhr) and if these effects are long-lasting. Lastly, much recent interest has been focused on the role of long noncoding RNAs (lncRNAs) in modulating mRNA translation and miRNA-dependent regulation [113]. While the repertoire of gonadotrope-expressed lncRNAs and their responses to leptin and/or GnRH signaling remain to be determined, lncRNAs may nonetheless be an additional level of direct or indirect control of GnRHR levels in the gonadotrope. Each of these potential regulators may translate into therapeutic targets for treating sub-optimal fertility. These potential RNA-binding protein, miRNA, and lncRNA regulatory pathways may ultimately be leveraged as novel therapeutic targets for treating sub-optimal fertility. Such strategies may, for example, be designed to suppress specific miRNAs [114] or promote ELAVL1/HuR stabilization of Gnrhr.

\section{Conclusions}

For decades, researchers have worked to determine the pathways ultimately leading to the secretion of LH and FSH, critical mediators of reproduction. One of the most important stimulators of the gonadotropins is GnRH from the hypothalamus. Therefore, the regulation of the $\mathrm{GnRH}$ receptor is critical for reproduction. Years of elegant studies 
have shown that Gnrhr is transcriptionally regulated. However, less is known about posttranscriptional control. Older and more recent studies by our lab and others have uncovered new layers of regulation of GnRHR expression (Figure 1). Given the evidence that leptin, a critical metabolic signal, may regulate miRNAs and RNA-binding proteins targeting Gnrhr mRNA, the study of post-transcriptional regulation of Gnrhr may inform future therapies targeted at optimizing reproductive capacity in women with metabolic challenges.

Author Contributions: Conceptualization, A.K.O. and A.M.M., writing-original draft, A.K.O. and A.M.M., writing-review and editing, A.K.O., M.C.M., G.V.C. and A.M.M. All authors have read and agreed to the published version of the manuscript.

Funding: Supported by NIH R01 HD059056 (G.V.C.); NIH R01HD087057 (G.V.C. and A.M.M.); NIH R01HD093461 (A.M.M., G.V.C. and M.C.M.), NIH R01DK113776-01 (G.V.C., A.M.M. and M.C.M.); NIGMS P20 GM103425 and P30GM11070 (Dr. Edgar Garcia-Rill).

Institutional Review Board Statement: Not applicable.

Informed Consent Statement: Not applicable.

Data Availability Statement: None.

Acknowledgments: Figure 1 was created with BioRender.com.

Conflicts of Interest: The authors declare no conflict of interest.

\section{References}

1. Bull, J.R.; Rowland, S.P.; Scherwitzl, E.B.; Scherwitzl, R.; Danielsson, K.G.; Harper, J. Real-world menstrual cycle characteristics of more than 600,000 menstrual cycles. NPJ Digit. Med. 2019, 2, 83. [CrossRef]

2. Allen, E. The oestrous cycle in the mouse. Am. J. Anat. 1922, 30, 297. [CrossRef]

3. Long, J.A.; Evans, H.M. The Oestrous Cycle in the Rat and its Associated Phenomena; University of California Press: Berkeley, CA, USA, 1922.

4. Odle, A.K.; Akhter, N.; Syed, M.M.; Allensworth-James, M.L.; Benes, H.; Melgar Castillo, A.I.; MacNicol, M.C.; MacNicol, A.M.; Childs, G.V. Leptin regulation of gonadotrope gonadotropin-releasing hormone receptors as a metabolic checkpoint and gateway to reproductive competence. Front. Endocrinol. 2017, 8, 367. [CrossRef] [PubMed]

5. Coss, D. Regulation of reproduction via tight control of gonadotropin hormone levels. Mol. Cell. Endocrinol. 2018, 463, 116-130. [CrossRef]

6. Bédécarrats, G.Y.; Kaiser, U.B. Differential regulation of gonadotropin subunit gene promoter activity by pulsatile gonadotropinreleasing hormone $(\mathrm{GnRH})$ in perifused L beta T2 cells: Role of GnRH receptor concentration. Endocrinology 2003, 144, $1802-1811$. [CrossRef]

7. Belchetz, P.E.; Plant, T.M.; Nakai, Y.; Keogh, E.J.; Knobil, E. Hypophysial responses to continuous and intermittent delivery of hypothalamic gonadotropin-releasing hormone. Science 1978, 202, 631-633. [CrossRef]

8. Clayton, R.N. Gonadotrophin-releasing hormone: Its actions and receptors. J. Endocrinol. 1989, 120, 11-19. [CrossRef] [PubMed]

9. Crowley, W.F., Jr.; Filicori, M.; Spratt, D.I.; Santoro, N.F. The physiology of gonadotropin-releasing hormone (GnRH) secretion in men and women. Recent Prog. Horm. Res. 1985, 41, 473-531. [PubMed]

10. Jobin, R.M.; Tomic, M.; Zheng, L.; Stojilkovic, S.S.; Catt, K.J. Gonadotropin-releasing hormone-induced sensitization of calciumdependent exocytosis in pituitary gonadotrophs. Endocrinology 1995, 136, 3398-3405. [CrossRef]

11. Lloyd, J.M.; Childs, G.V. Changes in the number of GnRH-receptive cells during the rat estrous cycle: Biphasic effects of estradiol. Neuroendocrinology 1988, 48, 138-146. [CrossRef]

12. Schang, A.L.; Quérat, B.; Simon, V.; Garrel, G.; Bleux, C.; Counis, R.; Cohen-Tannoudji, J.; Laverrière, J.N. Mechanisms underlying the tissue-specific and regulated activity of the Gnrhr promoter in mammals. Front. Endocrinol. 2012, 3, 162. [CrossRef]

13. Conn, P.M.; Knollman, P.E.; Brothers, S.P.; Janovick, J.A. Protein folding as posttranslational regulation: Evolution of a mechanism for controlled plasma membrane expression of a $G$ protein-coupled receptor. Mol. Endocrinol. 2006, 20, 3035-3041. [CrossRef]

14. Savoy-Moore, R.T.; Schwartz, N.B.; Duncan, J.A.; Marshall, J.C. Pituitary gonadotropin-releasing hormone receptors during the rat estrous cycle. Science 1980, 209, 942-944. [CrossRef]

15. Marian, J.; Cooper, R.L.; Conn, P.M. Regulation of the rat pituitary gonadotropin-releasing hormone receptor. Mol. Pharmacol. 1981, 19, 399-405. [PubMed]

16. Papavasiliou, S.S.; Zmeili, S.; Khoury, S.; Landefeld, T.D.; Chin, W.W.; Marshall, J.C. Gonadotropin-releasing hormone differentially regulates expression of the genes for luteinizing hormone alpha and beta subunits in male rats. Proc. Natl. Acad. Sci. USA 1986, 83, 4026-4029. [CrossRef]

17. Peng, C.; Fan, N.C.; Ligier, M.; Väänänen, J.; Leung, P.C. Expression and regulation of gonadotropin-releasing hormone (GnRH) and GnRH receptor messenger ribonucleic acids in human granulosa-luteal cells. Endocrinology 1994, 135, 1740-1746. [CrossRef] 
18. Minaretzis, D.; Jakubowski, M.; Mortola, J.F.; Pavlou, S.N. Gonadotropin-releasing hormone receptor gene expression in human ovary and granulosa-lutein cells. J. Clin. Endocrinol. Metab. 1995, 80, 430-434. [CrossRef]

19. Bull, P.; Morales, P.; Huyser, C.; Socías, T.; Castellón, E.A. Expression of GnRH receptor in mouse and rat testicular germ cells. Mol. Hum. Reprod. 2000, 6, 582-586. [CrossRef] [PubMed]

20. Lin, L.S.; Roberts, V.J.; Yen, S.S. Expression of human gonadotropin-releasing hormone receptor gene in the placenta and its functional relationship to human chorionic gonadotropin secretion. J. Clin. Endocrinol. Metab. 1995, 80, 580-585. [CrossRef] [PubMed]

21. Quintanar, J.L.; Salinas, E.; González, R. Gonadotropin-releasing hormone receptor in spinal cord neurons of embryos and adult rats. Neurosci. Lett. 2009, 461, 21-24. [CrossRef]

22. Leblanc, P.; Crumeyrolle, M.; Latouche, J.; Jordan, D.; Fillion, G.; L’Heritier, A.; Kordon, C.; Dussaillant, M.; Rostène, W.; Haour, F. Characterization and distribution of receptors for gonadotropin-releasing hormone in the rat hippocampus. Neuroendocrinology 1988, 48, 482-488. [CrossRef]

23. Ban, E.; Crumeyrolle-Arias, M.; Latouche, J.; Leblanc, P.; Heurtier, J.F.; Drieu, K.; Fillion, G.; Haour, F. GnRH receptors in rat brain, pituitary and testis; modulation following surgical and gonadotropin-releasing hormone agonist-induced castration. Mol. Cell. Endocrinol. 1990, 70, 99-107. [CrossRef]

24. Wilson, A.C.; Salamat, M.S.; Haasl, R.J.; Roche, K.M.; Karande, A.; Meethal, S.V.; Terasawa, E.; Bowen, R.L.; Atwood, C.S. Human neurons express type I GnRH receptor and respond to GnRH I by increasing luteinizing hormone expression. J. Endocrinol. 2006, 191, 651-663. [CrossRef] [PubMed]

25. Badr, M.; Pelletier, G. Characterization and autoradiographic localization of LHRH receptors in the rat brain. Synapse 1987, 1, 567-571. [CrossRef]

26. Wen, S.; Götze, I.N.; Mai, O.; Schauer, C.; Leinders-Zufall, T.; Boehm, U. Genetic identification of GnRH receptor neurons: A new model for studying neural circuits underlying reproductive physiology in the mouse brain. Endocrinology 2011, 152, 1515-1526. [CrossRef]

27. Hapgood, J.P.; Sadie, H.; van Biljon, W.; Ronacher, K. Regulation of expression of mammalian gonadotrophin-releasing hormone receptor genes. J. Neuroendocrinol. 2005, 17, 619-638. [CrossRef] [PubMed]

28. Janjic, M.M.; Stojilkovic, S.S.; Bjelobaba, I. Intrinsic and regulated gonadotropin-releasing hormone receptor gene transcription in mammalian pituitary gonadotrophs. Front. Endocrinol. 2017, 8, 221. [CrossRef] [PubMed]

29. Lee, V.H.; Lee, L.T.; Chow, B.K. Gonadotropin-releasing hormone: Regulation of the GnRH gene. FEBS J. 2008, $275,5458-5478$. [CrossRef]

30. Yasin, M.; Dalkin, A.C.; Haisenleder, D.J.; Kerrigan, J.R.; Marshall, J.C. Gonadotropin-releasing hormone (GnRH) pulse pattern regulates GnRH receptor gene expression: Augmentation by estradiol. Endocrinology 1995, 136, 1559-1564. [CrossRef]

31. Norwitz, E.R.; Cardona, G.R.; Jeong, K.H.; Chin, W.W. Identification and characterization of the gonadotropin-releasing hormone response elements in the mouse gonadotropin-releasing hormone receptor gene. J. Biol. Chem. 1999, 274, 867-880. [CrossRef]

32. Albarracin, C.T.; Kaiser, U.B.; Chin, W.W. Isolation and characterization of the $5^{\prime}$-flanking region of the mouse gonadotropinreleasing hormone receptor gene. Endocrinology 1994, 135, 2300-2306. [CrossRef] [PubMed]

33. Norwitz, E.R.; Xu, S.; Jeong, K.H.; Bédécarrats, G.Y.; Winebrenner, L.D.; Chin, W.W.; Kaiser, U.B. Activin A augments GnRHmediated transcriptional activation of the mouse GnRH receptor gene. Endocrinology 2002, 143, 985-997. [CrossRef]

34. Norwitz, E.R.; Xu, S.; Xu, J.; Spiryda, L.B.; Park, J.S.; Jeong, K.H.; McGee, E.A.; Kaiser, U.B. Direct binding of AP-1 (Fos/Jun) proteins to a SMAD binding element facilitates both gonadotropin-releasing hormone $(\mathrm{GnRH})$ - and activin-mediated transcriptional activation of the mouse GnRH receptor gene. J. Biol. Chem. 2002, 277, 37469-37478. [CrossRef]

35. Fortin, J.; Ongaro, L.; Li, Y.; Tran, S.; Lamba, P.; Wang, Y.; Zhou, X.; Bernard, D.J. Minireview: Activin signaling in gonadotropes: What does the FOX say ... to the SMAD? Mol. Endocrinol. 2015, 29, 963-977. [CrossRef]

36. Kumar, T.R.; Agno, J.; Janovick, J.A.; Conn, P.M.; Matzuk, M.M. Regulation of FSHbeta and GnRH receptor gene expression in activin receptor II knockout male mice. Mol. Cell. Endocrinol. 2003, 212, 19-27. [CrossRef] [PubMed]

37. Nathwani, P.S.; Kang, S.K.; Cheng, K.W.; Choi, K.C.; Leung, P.C. Regulation of gonadotropin-releasing hormone and its receptor gene expression by 17beta-estradiol in cultured human granulosa-luteal cells. Endocrinology 2000, 141, 1754-1763. [CrossRef]

38. Maya-Núñez, G.; Conn, P.M. Transcriptional regulation of the GnRH receptor gene by glucocorticoids. Mol. Cell. Endocrinol. 2003, 200, 89-98. [CrossRef]

39. Ngan, E.S.; Cheng, P.K.; Leung, P.C.; Chow, B.K. Steroidogenic factor-1 interacts with a gonadotrope-specific element within the first exon of the human gonadotropin-releasing hormone receptor gene to mediate gonadotrope-specific expression. Endocrinology 1999, 140, 2452-2462. [CrossRef] [PubMed]

40. Duval, D.L.; Nelson, S.E.; Clay, C.M. A binding site for steroidogenic factor-1 is part of a complex enhancer that mediates expression of the murine gonadotropin-releasing hormone receptor gene. Biol. Reprod. 1997, 56, 160-168. [CrossRef] [PubMed]

41. Pincas, H.; Laverrière, J.N.; Counis, R. Pituitary adenylate cyclase-activating polypeptide and cyclic adenosine $3^{\prime}, 5^{\prime}-$ monophosphate stimulate the promoter activity of the rat gonadotropin-releasing hormone receptor gene via a bipartite response element in gonadotrope-derived cells. J. Biol. Chem. 2001, 276, 23562-23571. [CrossRef] [PubMed]

42. Schang, A. Inside and outside the pituitary: Comparative analysis of Gnrhr expression provides insight into the mechanisms underlying the evolution of gene expression. J. Neuroendocrinol. 2015, 27, 177-186. [CrossRef] [PubMed] 
43. Loumaye, E.; Catt, K.J. Homologous regulation of gonadotropin-releasing hormone receptors in cultured pituitary cells. Science 1982, 215, 983-985. [CrossRef]

44. Katt, J.A.; Duncan, J.A.; Herbon, L.; Barkan, A.; Marshall, J.C. The frequency of gonadotropin-releasing hormone stimulation determines the number of pituitary gonadotropin-releasing hormone receptors. Endocrinology 1985, 116, 2113-2115. [CrossRef]

45. Tsutsumi, M.; Laws, S.C.; Sealfon, S.C. Homologous up-regulation of the gonadotropin-releasing hormone receptor in alpha T3-1 cells is associated with unchanged receptor messenger RNA (mRNA) levels and altered mRNA activity. Mol. Endocrinol. 1993, 7, 1625-1633. [CrossRef]

46. Tsutsumi, M.; Laws, S.C.; Rodic, V.; Sealfon, S.C. Translational regulation of the gonadotropin-releasing hormone receptor in alpha T3-1 cells. Endocrinology 1995, 136, 1128-1136. [CrossRef] [PubMed]

47. Yuen, T.; Ruf, F.; Chu, T.; Sealfon, S.C. Microtranscriptome regulation by gonadotropin-releasing hormone. Mol. Cell. Endocrinol. 2009, 302, 12-17. [CrossRef]

48. Godoy, J.; Nishimura, M.; Webster, N.J. Gonadotropin-releasing hormone induces miR-132 and miR-212 to regulate cellular morphology and migration in immortalized LbetaT2 pituitary gonadotrope cells. Mol. Endocrinol. 2011, 25, 810-820. [CrossRef]

49. Lannes, J.; L’Hôte, D.; Garrel, G.; Laverrière, J.N.; Cohen-Tannoudji, J.; Quérat, B. Rapid communication: A microRNA-132/212 pathway mediates GnRH activation of FSH expression. Mol. Endocrinol. 2015, 29, 364-372. [CrossRef]

50. Lannes, J.; L'Hôte, D.; Fernandez-Vega, A.; Garrel, G.; Laverrière, J.N.; Cohen-Tannoudji, J.; Quérat, B. A regulatory loop between miR-132 and miR-125b involved in gonadotrope cells desensitization to GnRH. Sci. Rep. 2016, 6, 31563. [CrossRef]

51. Han, D.X.; Sun, X.L.; Xu, M.Q.; Chen, C.Z.; Jiang, H.; Gao, Y.; Yuan, B.; Zhang, J.B. Roles of differential expression of microRNA21-3p and microRNA-433 in FSH regulation in rat anterior pituitary cells. Oncotarget 2017, 8, 36553-36565. [CrossRef]

52. Han, D.X.; Xiao, Y.; Wang, C.J.; Jiang, H.; Gao, Y.; Yuan, B.; Zhang, J.B. Regulation of FSH expression by differentially expressed miR-186-5p in rat anterior adenohypophyseal cells. PLOS ONE 2018, 13, e0194300. [CrossRef] [PubMed]

53. Ye, R.S.; Xi, Q.Y.; Qi, Q.; Cheng, X.; Chen, T.; Li, H.; Kallon, S.; Shu, G.; Wang, S.B.; Jiang, Q.Y.; et al. Differentially expressed miRNAs after GnRH treatment and their potential roles in FSH regulation in porcine anterior pituitary cell. PLoS ONE 2013, 8, e57156. [CrossRef]

54. Zhang, L.; Cai, Z.; Wei, S.; Zhou, H.; Zhou, H.; Jiang, X.; Xu, N. MicroRNA expression profiling of the porcine developing hypothalamus and pituitary tissue. Int. J. Mol. Sci. 2013, 14, 20326-20339. [CrossRef] [PubMed]

55. Wang, H.; Hastings, R.; Miller, W.L.; Kumar, T.R. Fshb-iCre mice are efficient and specific Cre deleters for the gonadotrope lineage. Mol. Cell. Endocrinol. 2016, 419, 124-138. [CrossRef]

56. Ahmed, K.; LaPierre, M.P.; Gasser, E.; Denzler, R.; Yang, Y.; Rülicke, T.; Kero, J.; Latreille, M.; Stoffel, M. Loss of microRNA-7a2 induces hypogonadotropic hypogonadism and infertility. J. Clin. Investig. 2017, 127, 1061-1074. [CrossRef]

57. Wang, H.; Graham, I.; Hastings, R.; Gunewardena, S.; Brinkmeier, M.L.; Conn, P.M.; Camper, S.A.; Kumar, T.R. Gonadotropespecific deletion of Dicer results in severely suppressed gonadotropins and fertility defects. J. Biol. Chem. 2015, 290, 2699-2714. [CrossRef] [PubMed]

58. Bernstein, E.; Caudy, A.A.; Hammond, S.M.; Hannon, G.J. Role for a bidentate ribonuclease in the initiation step of RNA interference. Nature 2001, 409, 363-366. [CrossRef] [PubMed]

59. Agarwal, V.; Bell, G.W.; Nam, J.W.; Bartel, D.P. Predicting effective microRNA target sites in mammalian mRNAs. eLife 2015, 4 . [CrossRef]

60. Odle, A.K.; Benes, H.; Melgar Castillo, A.; Akhter, N.; Syed, M.; Haney, A.; Allensworth-James, M.; Hardy, L.; Winter, B.; Manoharan, R.; et al. Association of Gnrhr mRNA with the stem cell determinant Musashi: A mechanism for leptin-mediated modulation of GnRHR expression. Endocrinology 2018, 159, 883-894. [CrossRef]

61. Fox, R.G.; Park, F.D.; Koechlein, C.S.; Kritzik, M.; Reya, T. Musashi signaling in stem cells and cancer. Annu. Rev. Cell Dev. Biol. 2015, 31, 249-267. [CrossRef]

62. Allensworth-James, M.; Banik, J.; Odle, A.; Hardy, L.; Lagasse, A.; Moreira, A.R.S.; Bird, J.; Thomas, C.L.; Avaritt, N.; Kharas, M.G.; et al. Control of the anterior pituitary cell lineage regulator POU1F1 by the stem cell determinant Musashi. Endocrinology 2021, 162. [CrossRef]

63. Terasaka, T.; Kim, T.; Dave, H.; Gangapurkar, B.; Nicholas, D.A.; Muñoz, O.; Terasaka, E.; Li, D.; Lawson, M.A. The RNA-binding protein ELAVL1 regulates GnRH receptor expression and the response to GnRH. Endocrinology 2019, 160, 1999-2014. [CrossRef] [PubMed]

64. Hinman, M.N.; Lou, H. Diverse molecular functions of Hu proteins. Cell. Mol. Life Sci. CMLS 2008, 65, 3168-3181. [CrossRef]

65. Brothers, K.J.; Wu, S.; DiVall, S.A.; Messmer, M.R.; Kahn, C.R.; Miller, R.S.; Radovick, S.; Wondisford, F.E.; Wolfe, A. Rescue of obesity-induced infertility in female mice due to a pituitary-specific knockout of the insulin receptor. Cell Metab. 2010, 12, 295-305. [CrossRef]

66. Wu, S.; Divall, S.; Nwaopara, A.; Radovick, S.; Wondisford, F.; Ko, C.; Wolfe, A. Obesity-induced infertility and hyperandrogenism are corrected by deletion of the insulin receptor in the ovarian theca cell. Diabetes 2014, 63, 1270-1282. [CrossRef] [PubMed]

67. Childs, G.; Odle, A.; MacNicol, M.; MacNicol, A. Leptin and its importance to reproduction. Endocrinology 2020. In Press.

68. Schwartz, M.W.; Peskind, E.; Raskind, M.; Boyko, E.J.; Porte, D., Jr. Cerebrospinal fluid leptin levels: Relationship to plasma levels and to adiposity in humans. Nat. Med. 1996, 2, 589-593. [CrossRef]

69. Frederich, R.C.; Hamann, A.; Anderson, S.; Lollmann, B.; Lowell, B.B.; Flier, J.S. Leptin levels reflect body lipid content in mice: Evidence for diet-induced resistance to leptin action. Nat. Med. 1995, 1, 1311-1314. [CrossRef] 
70. Grodstein, F.; Goldman, M.B.; Cramer, D.W. Body mass index and ovulatory infertility. Epidemiology 1994, 5, 247-250. [CrossRef]

71. Rich-Edwards, J.W.; Goldman, M.B.; Willett, W.C.; Hunter, D.J.; Stampfer, M.J.; Colditz, G.A.; Manson, J.E. Adolescent body mass index and infertility caused by ovulatory disorder. Am. J. Obstet. Gynecol. 1994, 171, 171-177. [CrossRef]

72. Zaadstra, B.M.; Seidell, J.C.; Van Noord, P.A.; te Velde, E.R.; Habbema, J.D.; Vrieswijk, B.; Karbaat, J. Fat and female fecundity: Prospective study of effect of body fat distribution on conception rates. BMJ 1993, 306, 484-487. [CrossRef]

73. Sir-Petermann, T.; Piwonka, V.; Pérez, F.; Maliqueo, M.; Recabarren, S.E.; Wildt, L. Are circulating leptin and luteinizing hormone synchronized in patients with polycystic ovary syndrome? Hum. Reprod. 1999, 14, 1435-1439. [CrossRef]

74. Charlton, H.M. Mouse mutants as models in endocrine research. Q. J. Exp. Physiol. 1984, 69, 655-676. [CrossRef]

75. Ingalls, A.M.; Dickie, M.M.; Snell, G.D. Obese, a new mutation in the house mouse. J. Hered. 1950, 41, 317-318. [CrossRef] [PubMed]

76. Swerdloff, R.S.; Batt, R.A.; Bray, G.A. Reproductive hormonal function in the genetically obese (ob/ob) mouse. Endocrinology 1976, 98, 1359-1364. [CrossRef] [PubMed]

77. Barash, I.A.; Cheung, C.C.; Weigle, D.S.; Ren, H.; Kabigting, E.B.; Kuijper, J.L.; Clifton, D.K.; Steiner, R.A. Leptin is a metabolic signal to the reproductive system. Endocrinology 1996, 137, 3144-3147. [CrossRef]

78. Chehab, F.F.; Lim, M.E.; Lu, R. Correction of the sterility defect in homozygous obese female mice by treatment with the human recombinant leptin. Nat. Genet. 1996, 12, 318-320. [CrossRef]

79. Karlsson, C.; Lindell, K.; Svensson, E.; Bergh, C.; Lind, P.; Billig, H.; Carlsson, L.M.; Carlsson, B. Expression of functional leptin receptors in the human ovary. J. Clin. Endocrinol. Metab. 1997, 82, 4144-4148. [CrossRef] [PubMed]

80. Ratra, D.V.; Elias, C.F. Chemical identity of hypothalamic neurons engaged by leptin in reproductive control. J. Chem. Neuroanat. 2014, 61-62, 233-238. [CrossRef]

81. Smith, J.T.; Acohido, B.V.; Clifton, D.K.; Steiner, R.A. KiSS-1 neurones are direct targets for leptin in the ob/ob mouse. J. Neuroendocrinol. 2006, 18, 298-303. [CrossRef]

82. Akhter, N.; CarlLee, T.; Syed, M.M.; Odle, A.K.; Cozart, M.A.; Haney, A.C.; Allensworth-James, M.L.; Benes, H.; Childs, G.V. Selective deletion of leptin receptors in gonadotropes reveals activin and GnRH-binding sites as leptin targets in support of fertility. Endocrinology 2014, 155, 4027-4042. [CrossRef] [PubMed]

83. Landrier, J.F.; Derghal, A.; Mounien, L. MicroRNAs in obesity and related metabolic disorders. Cells 2019, 8, 859. [CrossRef] [PubMed]

84. Derghal, A.; Astier, J.; Sicard, F.; Couturier, C.; Landrier, J.F.; Mounien, L. Leptin modulates the expression of miRNAs-targeting POMC mRNA by the JAK2-STAT3 and PI3K-akt pathways. J. Clin. Med. 2019, 8, 2213. [CrossRef]

85. Meerson, A.; Yehuda, H. Leptin and insulin up-regulate miR-4443 to suppress NCOA1 and TRAF4, and decrease the invasiveness of human colon cancer cells. BMC Cancer 2016, 16, 882. [CrossRef] [PubMed]

86. Yang, W.H.; Chang, A.C.; Wang, S.W.; Wang, S.J.; Chang, Y.S.; Chang, T.M.; Hsu, S.K.; Fong, Y.C.; Tang, C.H. Leptin promotes VEGF-C production and induces lymphangiogenesis by suppressing miR-27b in human chondrosarcoma cells. Sci. Rep. 2016, 6 , 28647. [CrossRef]

87. Zhai, X.; Cheng, F.; Ji, L.; Zhu, X.; Cao, Q.; Zhang, Y.; Jia, X.; Zhou, Q.; Guan, W.; Zhou, Y. Leptin reduces microRNA-122 level in hepatic stellate cells in vitro and in vivo. Mol. Immunol. 2017, 92, 68-75. [CrossRef]

88. Allensworth-James, M.L.; Odle, A.K.; Lim, J.; LaGasse, A.N.; Miles, T.K.; Hardy, L.L.; Haney, A.C.; MacNicol, M.C.; MacNicol, A.M.; Childs, G.A.-O. Metabolic signalling to somatotrophs: Transcriptional and post-transcriptional mediators. J. Endocrinol. 2020, 32, e12883. [CrossRef]

89. Hasuwa, H.; Ueda, J.; Ikawa, M.; Okabe, M. miR-200b and miR-429 function in mouse ovulation and are essential for female fertility. Science 2013, 341, 71-73. [CrossRef]

90. Eisenberg, I.; Nahmias, N.; Novoselsky Persky, M.; Greenfield, C.; Goldman-Wohl, D.; Hurwitz, A.; Haimov-Kochman, R.; Yagel, S.; Imbar, T. Elevated circulating micro-ribonucleic acid (miRNA)-200b and miRNA-429 levels in anovulatory women. Fertil. Steril. 2017, 107, 269-275. [CrossRef]

91. Granger, A.; Ngo-Muller, V.; Bleux, C.; Guigon, C.; Pincas, H.; Magre, S.; Daegelen, D.; Tixier-Vidal, A.; Counis, R.; Laverriere, J.N. The promoter of the rat gonadotropin-releasing hormone receptor gene directs the expression of the human placental alkaline phosphatase reporter gene in gonadotrope cells in the anterior pituitary gland as well as in multiple extrapituitary tissues. Endocrinology 2004, 145, 983-993. [CrossRef]

92. Wen, S.; Ai, W.; Alim, Z.; Boehm, U. Embryonic gonadotropin-releasing hormone signaling is necessary for maturation of the male reproductive axis. Proc. Natl. Acad. Sci. USA 2010, 107, 16372-16377. [CrossRef]

93. Pointis, G.; Mahoudeau, J.A. [Study of Leydig cells and gonadotropin activity in 14-18 days old fetal mouse (author's transl)] Ann. D'endocrinol. 1979, 40, 431-432.

94. Herbison, A.E. Control of puberty onset and fertility by gonadotropin-releasing hormone neurons. Nat. Rev. Endocrinol. 2016, 12, 452-466. [CrossRef] [PubMed]

95. Bjelobaba, I.; Janjic, M.M.; Kucka, M.; Stojilkovic, S.S. Cell type-specific sexual dimorphism in rat pituitary gene expression during maturation. Biol. Reprod. 2015, 93, 21. [CrossRef]

96. Ahima, R.S.; Prabakaran, D.; Flier, J.S. Postnatal leptin surge and regulation of circadian rhythm of leptin by feeding. Implications for energy homeostasis and neuroendocrine function. J. Clin. Investig. 1998, 101, 1020-1027. [CrossRef] 
97. Jaquet, D.; Leger, J.; Levy-Marchal, C.; Oury, J.F.; Czernichow, P. Ontogeny of leptin in human fetuses and newborns: Effect of intrauterine growth retardation on serum leptin concentrations. J. Clin. Endocrinol. Metab. 1998, 83, 1243-1246. [CrossRef] [PubMed]

98. Delahaye, F.; Breton, C.; Risold, P.Y.; Enache, M.; Dutriez-Casteloot, I.; Laborie, C.; Lesage, J.; Vieau, D. Maternal perinatal undernutrition drastically reduces postnatal leptin surge and affects the development of arcuate nucleus proopiomelanocortin neurons in neonatal male rat pups. Endocrinology 2008, 149, 470-475. [CrossRef]

99. Lopez-Gallardo, M.; Anton-Fernandez, A.; Llorente, R.; Mela, V.; Llorente-Berzal, A.; Prada, C.; Viveros, M.P. Neonatal treatment with a pegylated leptin antagonist induces sexually dimorphic effects on neurones and glial cells, and on markers of synaptic plasticity in the developing rat hippocampal formation. J. Neuroendocrinol. 2015, 27, 658-669. [CrossRef] [PubMed]

100. Coupe, B.; Amarger, V.; Grit, I.; Benani, A.; Parnet, P. Nutritional programming affects hypothalamic organization and early response to leptin. Endocrinology 2010, 151, 702-713. [CrossRef]

101. Attig, L.; Larcher, T.; Gertler, A.; Abdennebi-Najar, L.; Djiane, J. Postnatal leptin is necessary for maturation of numerous organs in newborn rats. Organogenesis 2011, 7, 88-94. [CrossRef]

102. Mela, V.; Diaz, F.; Vazquez, M.J.; Argente, J.; Tena-Sempere, M.; Viveros, M.P.; Chowen, J.A. Interaction between neonatal maternal deprivation and serum leptin levels on metabolism, pubertal development, and sexual behavior in male and female rats. Biol. Sex. Differ. 2016, 7, 2. [CrossRef] [PubMed]

103. Mela, V.; Diaz, F.; Lopez-Rodriguez, A.B.; Vazquez, M.J.; Gertler, A.; Argente, J.; Tena-Sempere, M.; Viveros, M.P.; Chowen, J.A Blockage of the neonatal leptin surge affects the gene expression of growth factors, glial proteins, and neuropeptides involved in the control of metabolism and reproduction in peripubertal male and female rats. Endocrinology 2015, 156, 1571-1581. [CrossRef]

104. Chehab, F.F.; Mounzih, K.; Lu, R.; Lim, M.E. Early onset of reproductive function in normal female mice treated with leptin. Science 1997, 275, 88-90. [CrossRef]

105. Ahima, R.S.; Dushay, J.; Flier, S.N.; Prabakaran, D.; Flier, J.S. Leptin accelerates the onset of puberty in normal female mice. J. Clin. Investig. 1997, 99, 391-395. [CrossRef] [PubMed]

106. Cheung, C.C.; Thornton, J.E.; Kuijper, J.L.; Weigle, D.S.; Clifton, D.K.; Steiner, R.A. Leptin is a metabolic gate for the onset of puberty in the female rat. Endocrinology 1997, 138, 855-858. [CrossRef]

107. Schwartz, M.W.; Seeley, R.J.; Woods, S.C.; Weigle, D.S.; Campfield, L.A.; Burn, P.; Baskin, D.G. Leptin increases hypothalamic pro-opiomelanocortin mRNA expression in the rostral arcuate nucleus. Diabetes 1997, 46, 2119-2123. [CrossRef] [PubMed]

108. Akira, S.; Maeda, K. Control of RNA stability in immunity. Annu. Rev. Immunol. 2021. [CrossRef]

109. Ho, J.J.; Marsden, P.A. Competition and collaboration between RNA-binding proteins and microRNAs. Wiley Interdiscip. Rev. RNA 2014, 5, 69-86. [CrossRef] [PubMed]

110. Wang, J.; Hjelmeland, A.B.; Nabors, L.B.; King, P.H. Anti-cancer effects of the HuR inhibitor, MS-444, in malignant glioma cells. Cancer Biol. 2019, 20, 979-988. [CrossRef] [PubMed]

111. Wu, M.; Tong, C.W.S.; Yan, W.; To, K.K.W.; Cho, W.C.S. The RNA binding protein HuR: A promising drug target for anticancer therapy. Curr. Cancer Drug Targets 2019, 19, 382-399. [CrossRef]

112. Muralidharan, R.; Mehta, M.; Ahmed, R.; Roy, S.; Xu, L.; Aubé, J.; Chen, A.; Zhao, Y.D.; Herman, T.; Ramesh, R.; et al. HuRtargeted small molecule inhibitor exhibits cytotoxicity towards human lung cancer cells. Sci. Rep. 2017, 7, 9694. [CrossRef] [PubMed]

113. Statello, L.; Guo, C.J.; Chen, L.L.; Huarte, M. Gene regulation by long non-coding RNAs and its biological functions. Nat. Rev. Mol. Cell Biol. 2021, 22, 96-118. [CrossRef] [PubMed]

114. Raue, R.; Frank, A.C.; Syed, S.N.; Brüne, B. Therapeutic targeting of MicroRNAs in the tumor microenvironment. Int. J. Mol. Sci. 2021, 22, 2210. [CrossRef] [PubMed] 